\title{
The nature of management
}

\author{
Jing $\mathrm{Fu}^{1, \mathrm{a}}$ and Jin $\mathrm{Pu}^{2, \mathrm{~b}}$ \\ ${ }^{1}$ State-Owned Assets Administrative office, China West Normal University, Nanchong, Sichuan \\ 637002, China \\ ${ }^{2}$ Institute of Theoretical Physics, China West Normal University, Nanchong, Sichuan 637002, China \\ aEmail :fujing0915@163.com; ${ }^{\mathrm{b}}$ Email :red6011@126.com
}

Keywords: Management; Moral Choice; Ethics.

Abstract. The correct understanding of the nature of management is conducive to improve the efficiency of management. By reviewing the different disciplines and management science theories on the essence of management, in this paper we combine the theory of ethics to analyze, and believe that the nature of management is to realize the value by harmonizing the conflict of interests through moral choice, and the nature of management is described from three aspects: Individual, Organization and Industry. At the same time, I believe that efficiency is the ultimate goal of management, and the correct management comes from the correct values.

\section{Introduction}

The nature of management is to coordinate the conflicts of interests through moral choice to realize the value.

The management activity has existed since ancient times, but it is a new subject to study the management formally. To define a generalized and practical management, it can be seen as such an activity, which play a certain role, so as to effectively access, distribute and use human effort and material resources, to achieve a goal[1].

Management involves widely, scholars in various fields have their different understanding for it. From an economic point of view, management is a kind of productivity and economic resources. Jean Baptiste Say, a French economist, is the first to admit that there are fourth elements of production. Say said that some "adventurers" (entrepreneur) has only a part of enterprises, they often borrow money or ask for a business partnership with others, so these "adventurers" become the managers who manage others. When combining the three elements of land, labor and capital together he takes another risk [2]. Say is the first to put forward management as an independent factor of production. From the sociological point of view, management is a kind of authority system[3]. From a historical perspective, management is the action of a few upper class members to determine the actions of ordinary members. For example, the prime minister is second to emperor, is now the senior management staff. But now, it has formed a series of rules and regulations, workers are both the object of management and the main body of management.

Since then, the theory of management science, scholars and schools have to define management. Fayol, a representative of classical management theory, thinks that management is a kind of activity with special functions, and it is more emphasis on the requirements of managers. Simon, a representative of decision theory school, thinks that management is decision-making. Scientific management scholar believes that management is the process of achieving group goals through the efforts and achievements of others. The behavioral science scholar believes that management is a kind of activity that can harmonize interpersonal relationships and stimulate people's enthusiasm in order to achieve common goals. The Systematic scholar believes that management is a kind of activity that can harmonize the various subsystems in the organization, and makes it adapt to the environment. Drucker, the representative of empiricism scholar, thinks that management is a kind of practice, and its essence is not knowing but doing, and its verification is not in logic but in the results. Koontz, a representative of operation scholar, regards management as a skill that work through others and work with others, cooperate with the team members to complete the work, and clear obstacles and achieve goals effectively. 
To sum up, management is a kind of activity of the subject (manager) through the media (material technology system, knowledge information system, incentive system) to the object (human, financial, material, information, time, space). The center of management activity is human, which can not do without benefit and morality. Broadly speaking, everyone is a manager. Kant, a German philosopher, thinks that every man is his own legislator, so man is both a manager and a managed. Kant also thinks that the person is the goal, but not the tool, so people are both the object of management and the purpose of management, and the purpose of management is to realize the all-round development of human beings. We can see that the common of these definitions is that we can achieve the goal by harmonizing the relationship. Based on this, I think the nature of management is to harmonize the conflicts of interests through moral choice to realize the value.

\section{Management from a personal point of view}

From a personal point of view, it needs to achieve self-management. There is no conflict, and there is no need for management. Conflict is the contradiction between ideal and reality. In this process of management, the manager is himself, and the managed is time, space and other resources. For example, the exam is coming, do you choose to go out to play or to read? This is a choice. And for example, do you rely on your family's ability to find a more relaxed, effective and good work or through your own efforts to build your own business? there is a choice, and we can only choose one. Choosing to play may have to bear the risk of unsatisfactory exam results, and choose to rely on your family's ability to find a job may have to assume that you do not have the ability, or that you do not like the work yourself, and it can not make you happy. So this is a balance between the interests of the choice, you have to measure what you want, how much (degree) and what means, methods, and ways to get what you want. At this point, values determine our choice. Hedonist may choose the former, and diligent people will choose the latter. Therefore, the process of self-management is guided by their own values through moral choice, coordination of interest conflicts, and ultimately achieving their goals (i.e., value). This is a very painful process, because the decision to get some interests at the same time you might have to give up another interest, you will be in a dilemma, which requires you to measure what for you is the most important. It's like metamorphosis, the butterfly is beautiful, but the selection and transformation process of the butterfly is very painful. So, this requires a self-management, but also a superb self-management, in order to better realize the value.

\section{Management from the perspective of organization}

From the perspective of organization, management is also a process of balancing the interest conflict. In the organization, because of the different interest requirements, the conflict exists between the Department, between people, and between the individual and the organization. For example, at the board of directors, the production department wants to update the equipment in order to improve the efficiency, but the financial department may not want to update the device from a cost saving point of view. Thus, company executives need to balance the conflict of interest between the two stakeholders, and from the company's point of view, whether or not these devices need to be updated or other better solutions can be adopted. Also, it is a process of moral choice. What is the only economic benefits or will take into account the current equipment has been aging, there will be problems of high consumption, waste of social resources and other issues. For example, whether companies treats the enterprise employees as a tool to make money or as a whole needs of people, whether companies only consider the increase in material wealth or take into account the overall development, employee occupation health, this is a matter for the conflict of interests and humanitarian. Companies want to make more money, and employees want a little more, which is now more prominent labor troubles. This series of problems are related to ethical issues, so the decision to solve these problems is a matter of moral choice. In fact, the decision is the choice, and the choice is the balance, which is based on values. Because people's values guide their behavior, the enterprise managers will be under the guidance of the concept of self-value to make decisions on the treatment 
of employees and make some system to protect the interests of the employees. If companies treat the staff as a whole person rather than a matter, pay much attention to all-round development of employees and companies, then companies will transfer their interests, to meet the interests of employees, coordinate the conflict with each other, and find the two best fit point, then the above problem will be overcomed, and the company will be healthy and orderly developed. Barnard defines "organization" as "human cooperative behavior". It can be seen that the coordination of member behavior is the value of the existence of the organization, is the task of management. In the organization, the use of power to surrender to you may infringe upon others, and the best management effect is to rationally follow in the leadership of employees, thus companies will form the ideal and synergy team to maximize the efficiency of the company.

\section{Management from the perspective of industry}

From the perspective of industry, it also involves the conflict of interest between the organization and the organization, between the organization and the nature, the organization and the country. For example, the two factories are hoping to get the financial support from government, but the amount is certain, then the two will have a conflict, or you are more than I am or you are less than I am. If the factory of A opened by a leader's relatives is a high pollution, and the factory of B is a very general but more friendly to environment, thus where the money flows to, or who obtains more? It is also a matter of moral choice. Fear of authority who may be more or all funds allocated to the factory of A, but a more public interest who may be put the funds to the factory of B. For example, whether the enterprise is only concerned about their own economic interests or to assume the social responsibility to protect the environment at the same time? These are all a matter of choice. Drucker advocated that " organization" should not only serve the people, establish and maintain the internal cooperative relations, but also must serve the society and maintain the normal operation of a society. Here, we can see that the company is also shouldering social responsibility. Enterprises should pay attention to the protection and rational use of resources in order to achieve the goal of sustainable development.

\section{Conclusion}

Therefore, the essence of management is to coordinate the conflicts of interests through moral choice to realize the value. The three core categories of management is the humanity and use, public and private interest, fairness and efficiency, the public and private interest is always the core of conflict management, and efficiency is the ultimate goal of management. We should not only learn to manage in real life, but also have excellent management skills, and feel for others so as to find the best combination of conflict, to achieve the greatest value at the expense of minimum cost. This is also the best management goal. At the same time, management cannot be separated from the concept of value, the correct management comes from the correct values, so we need to establish the correct values..

\section{Acknowledgement}

This work is supported by the starting fund of China West Normal University with Grant No. 08B059, by FANEDD with Grant No. 201319, and by the Innovative Research Team in College of Sichuan Province with Grant No. 13TD0003, and by Sichuan Natural Science Foundation with Grant No. 16ZB0178.

\section{References}

[1] Daniel A. Wren. Evolution of Management Thought [M]. China Social Sciences Press, 2004(10 ): P2

[2] Daniel A. Wren. Evolution of Management Thought [M]. China Social Sciences Press, 2004(10):P48

[3] Zhang Yongkui, Sun Jun, Modern Management Mcience [M]. China Machine Press , 2007(9 ): P2 